\title{
Formation of an ectocarpoid epiflora on blades of Laminaria digitata
}

\author{
G. Russell \\ Hartley Botanical Laboratories, The University, Liverpool L69 3BX, England
}

\begin{abstract}
The development of ectocarpoid algae on blades of Laminaria digitata (Hudson) Lamouroux has been followed by punching discs in a median line from proximal to distal ends of the blade, and culturing these in the laboratory for a period of $4 \mathrm{wk}$. Laminaria sporophytes were collected from exposed-shore and sheltered-shore populations on the Isle of Man (UK) but no difference could be detected either in species composition of their epifloras or in distribution and growth of ectocarpoid algae along the frond. The epiphyton was dominated by the microthallus of Ectocarpus fasciculatus, which gave rise to another generation of fertile offspring during the culture period. It is concluded that the success of E. fasciculatus may be due to its particular growth and reproductive characteristics which enable it to maintain a presence on the Laminaria blade throughout its phase of rapid growth.
\end{abstract}

\section{INTRODUCTION}

As a substrate for algal epiphytes, the Laminaria sporophyte blade is both advantageous and hazardous. An epiphyte will receive more light than its counterpart below the forest canopy and, as a result of increased water movement over the thallus, it may have access to more nutrients than in the relatively static conditions of the understorey. Factors such as these ought to be conducive to rapid growth and maturation.

However, the growth characteristics of the host may also be a source of difficulty for the epiphyte. Any spore settling at the distal end of the blade may well be discarded, together with senescent host tissue, before its thallus development can proceed. Conversely, any reproductively mature epiphyte will almost certainly have colonised the host at a point proximal to that at which it attained this state. Successful completion of its life-history implies, therefore, that development of the epiphyte has at least kept pace with that of its host blade.

Studies of epifloras of European laminarians have been made by Marshall (1960), Norton (1966, 1970), South (1966), Kain (1971), Gayral and Cosson (1973), and others (see Kain, 1979). Interpretations of epiphyte distribution patterns, when made, have tended to reflect the prevailing condition of the physical environment. For example, stipes of Laminaria hyperborea may develop zonal patterns of red algae in evident response to the incident irradiance (Marshall, 1960). South (1966), however, has considered the age of host tissue to be of importance in determining epiphyte distribution on Chorda filum.

Tokida (1960) listed the algal epiphytes which, up to that date, had been reported to occur on Laminaria species. Taking the genus as a whole, the ratio of red: brown algal species occurring as epiphytes solely on stipe or holdfast was approximately 4:1 whereas on blades, the ratio was $0.5: 1$. The number of species common to stipe and blade was surprisingly low 7 out of 129) so that the floristic similarity (calculated by means of the Sorensen coefficient) was only $11 \%$. The transition from stipe to blade is therefore characterised by a sudden change in the composition of the epiflora that may not be explicable solely in terms of physical gradients

Tokida's data are also of interest in that they show the brown algal epiphytes of the Laminaria blade to belong mainly to the Order Ectocarpales s. lat. whereas members of other brown algal groups such as the Order Sphacelariales tend to be stipe epiphytes. Members of the Order Desmarestiales and Order Laminariales have also been reported as common stipe epiphytes of Laminaria hyperborea by Harkin (1981). It is by no means clear either how ectocarpoid algae are more successful blade epiphytes than other potential colonisers, or what the nature of their adaptation to 
their host tissues is. The chief purpose of this investigation was therefore to examine the process of colonisation of Laminaria blades by their ectocarpoid epiphytes, and to record their development in culture

\section{MATERIALS AND METHODS}

The host species selected for study was Laminaria digitata (Hudson) Lamouroux; it was collected in mid April 1982 from 2 contrasting sites on the Isle of Man, UK. The sites were Derbyhaven $\left(54^{\circ} 4^{\prime} 30^{\prime \prime} \mathrm{N}: 4^{\circ} 36^{\prime}\right.$

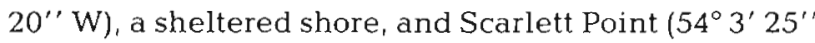
$\mathrm{N}: 4^{\circ} 39^{\prime} 30^{\prime \prime} \mathrm{W}$ ), an exposed shore. Altogether, 15 sporophytes were collected, 8 from Scarlett Point and 7 from Derbyhaven. The blades of these plants varied in length from 33 to $86 \mathrm{~cm}$ (Figs. 3 and 4). The Scarlett Point plants had the robust, narrow and deeply digitate frond of $f$. stenophylla Harvey, whereas those from Derbyhaven had the thin, expanded and relatively undivided form of $f$. cucullata (Le Jolis) Svendsen and Kain. The plants were selected solely on the basis of their apparent freedom from epiphytes; they were placed in polythene bags and then brought back to the laboratory at Liverpool for analysis. All but 1 plant proved to have completed 2 yr of growth, the solitary exception ( $f$. cucullata plant No. 5, Fig. 3) being only 1 yr old.

The incidence of epiphytes was assessed from discs punched from the blades and subsequently cultured. The discs were approximately $3.8 \mathrm{~mm}$ in diameter, each disc surface therefore having an area of approximately $11 \mathrm{~mm}^{2}$. From each frond 25 discs were punched in median and equidistant series, starting from a point just above the junction of blade and stipe and ending just behind the distal and of the blade. The discs were thus located at approximately corresponding positions along the blades, although inter-disc distances varied with blade length (Figs. 3 and 4).

In order to minimise the risk of microbial or microflagellate blooms developing in culture, the discs were surface-sterilised using a molecular iodine solution, as follows:

\section{Stock solution}

$\begin{array}{ll}\text { Iodine } & 2.5 \mathrm{~g} \\ \text { Potassium iodide } & 1.6 \mathrm{~g} \\ \text { Boric acid } & 1.6 \mathrm{~g} \\ 98 \% \text { Ethanol to } 100 \mathrm{~cm}^{3} & \end{array}$

The sterilant was prepared by adding $0.4 \mathrm{~cm}^{3}$ of stock solution to $100 \mathrm{~cm}^{3}$ seawater. Discs were placed in sterilant for 3-4 min, then washed in 2 changes of sterile seawater, and transferred to culture medium. Disc treatments were carried out in 'Repliboxes', sterile polypropylene culture vessels divided into 25 compartments, each of which contained 1 disc together with approximately $5 \mathrm{~cm}^{3}$ of the appropriate medium. The culture medium was based on that described by von Stosch (1964) but supplemented with soil extract at the rate of $5 \mathrm{~cm}^{3} \mathrm{1}^{-1}$. Discs were cultured in a growth room at $10^{\circ} \mathrm{C}$ with irradiance of approximately $11 \mathrm{wm}^{-2}$ in $8: \overline{16}$ h daylengths. The discs were established in culture on April 14th and harvested on May 13th 1982, when they were scanned for the presence of epiphytes under a low-power binocular microscope. Only the illuminated surfaces of the discs were scanned; these usually carried a much greater cover of epiphytes than the shaded surfaces. The epiphytes present proved to be almost entirely ectocarpoid in character, and the few that belonged to other taxonomic groups were discounted. Ectocarpoid abundance was estimated using the crude scale illustrated in Fig. 1 ; this, in effect, is the Hult-Sernander cover scale.

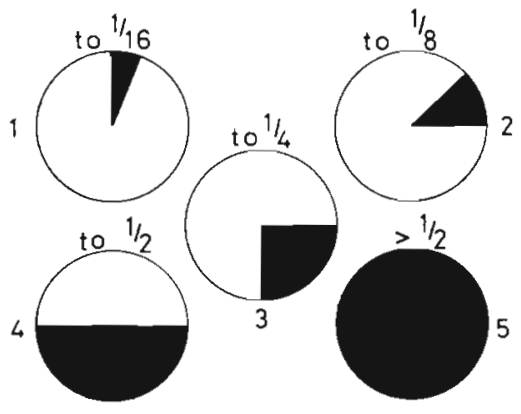

Fig. 1. Laminaria digitata. Abundance scale used for measuring ectocarpoid algal cover on cultured blade discs

The principal source of error in this method, was the occasional partial separation of the 2 cortical layers of the discs caused by rupture of the medullary tissue during the punching operation. This permitted the iodine sterilant to penetrate the disc and thus to kill all or part of the host tissue together with its ectocarpoid associates. Dead discs were recognisable after about 1 wk in culture by their bleached appearance. Otherwise the action of the iodine seemed fairly gentle, any pre-existing epiphyte filaments protruding from the disc surface were killed, but their bases or internal filaments survived.

\section{RESULTS}

By the end of the fourth week in culture, ectocarpoid algae were present on most discs from both Laminaria samples (Fig. 2a). These constituted the bulk of the biota, but other organisms present included cyanobacteria, small green algae, diatoms and nematode worms. Some of these may prove to be specifically linked with $L$. digitata but accurate figures on their association have still to be obtained. The ectocarpoid 

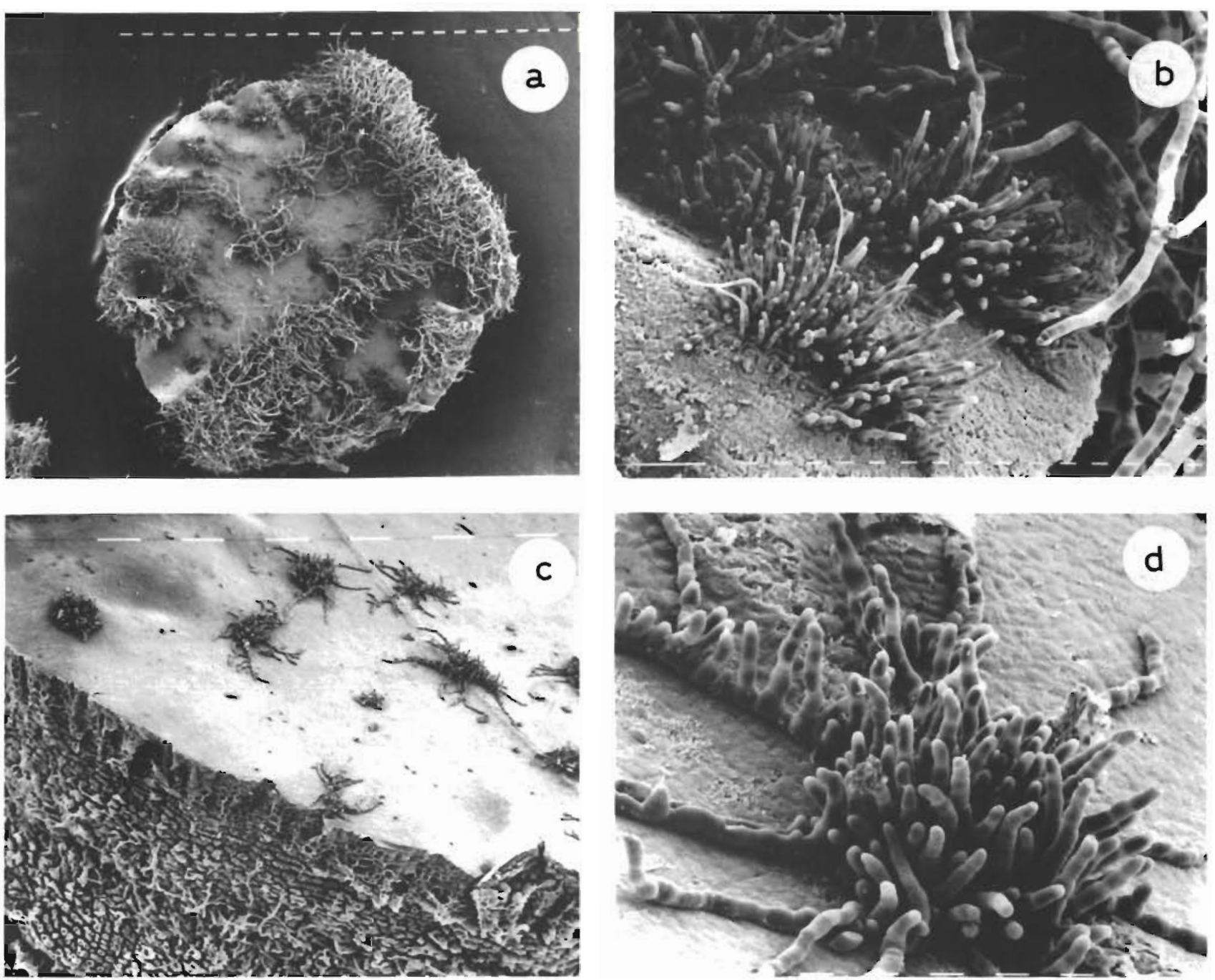

Fig. 2. Laminaria digitata. Scanning electron micrographs of cultured blacle discs. (a) Illuminated surface of entire disc showing extensive cover by ectocarpoid algae, almost entirely Ectocarpus fasciculatus. Scale bars $=100 \mu \mathrm{m}$. (b) Detail of ectocarpoid algae emerging from inner tissues of Laminaria disc. Scale bars $=10 \mu \mathrm{m}$. (c) Edge of disc showing young E. fasciculatus of second generation at various stages in development. Scale bars $=100 \mu \mathrm{m}$. (d) Detail of second-generation Ectocarpus showing radiating horizontal filaments bearing upright branches. The short cells in the older upright filaments in the centre of the plant are loculi of developing plurilocular sporangia. Scale bars $=10 \mu \mathrm{m}$

algae were either emergent from the inner tissues of the disc (Fig. 2b) or closely adpressed to its outer suitface. The filaments had become fertile and their progeny could be seen at various stages in development in available disc surfaces (Fig. 2c); in certain cases, these too had become fertile (Fig 2d). The most abundant alga in both sample sets was the microthallus of Ectocarpus fasciculatus Harvey, as described by Jaasund (1965) and Baker and Evans (1971). Laminariocolax tomentosoides (Farlow) Kylin was also present in small amounts, but no other ectocarpoid species was observed.

From the presence of ectocarpoid epiphytes on discs of Laminaria digitata f. cucullata (Fig. 3) it can be seen that the majority of discs $(74 \%)$ had been colonised at some time prior to culturing. Fig. 3 also gives the frequency of ectocarpoid epiphytes at each of the 25 blade loci, and it is evident that the proximal parts of the blade have the fewest records and distal parts the greatest numbers. Data from f. stenophylla blades (Fig. 4) reveal slightly fewer ectocarpoid records $(64 \%)$; the shape of the frequency graph also differs a little from that obtained from $f$. cucullata discs. However, the overall trend of distal increase in epiphyte frequency is in substantial agreement with that in Fig. 3.

The abundance of epiphytes on both Laminaria samples (Fig. 5) reveals that there is no real difference between samples either in amount of epiphyte cover or in their patterns of epiphyte distribution. The mean 


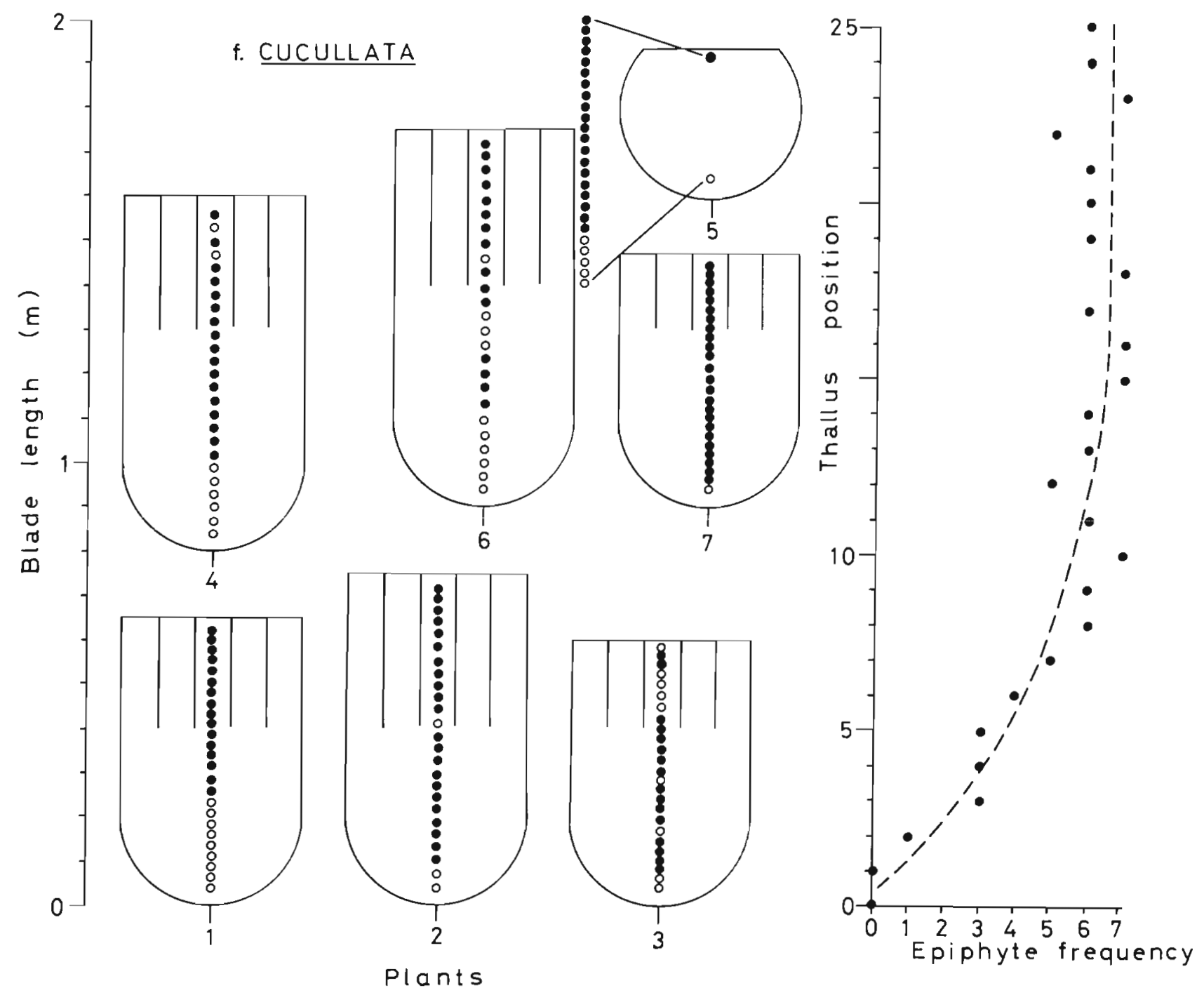

Fig. 3. Laminaria digitata f. cucullata. Sporophytes, blade length only being to scale. Superimposed upon blade diagrams are positions of the series of punched discs. Filled circles: presence of ectocarpoid algae on cultured discs; open circles: absence. The graph depicts ectocarpoid frequency at each of the 25 positions from which blade discs were removed. Hatched line: best fit

cover values calculated for each of the 25 blade loci, and from the pooled sample sets, are illustrated in Fig. 6. The resulting graph shows clearly the pattern of epiphyte growth along the frond. It should be noted that the cover values have not been log-transformed because of the exponential nature of the abundance scale adopted.

\section{DISCUSSION AND CONCLUSIONS}

The results indicate that ectocarpoid algae are the principal components of the epiflora of the Laminaria digitata blade, and are in agreement with the observations of Tokida (1960). They also reveal that colonisation of the blade is a continuous process which begins close to the transition zone between blade and stipe. Initiation of the epiflora has therefore been accomplished on blade tissue that is apparently epiphytefree, a fact which could not be determined by direct examination of field material. Ectocarpus fasciculatus, the chief component of the epiflora, attains reproductive maturity before its substrate has been shed from the blade's distal end. It will therefore have little difficulty in contributing successive generations of progeny to blade tissue throughout the life of the host plant. Too much should not be read into the precise form of the growth curve on Fig. 6, however. This has been based upon blade discs obtained at a particularly rapid phase in blade growth (Sundene, 1962; Lüning, 1982). The culture environment is artificial in that the discs have ceased to grow and that they have been 


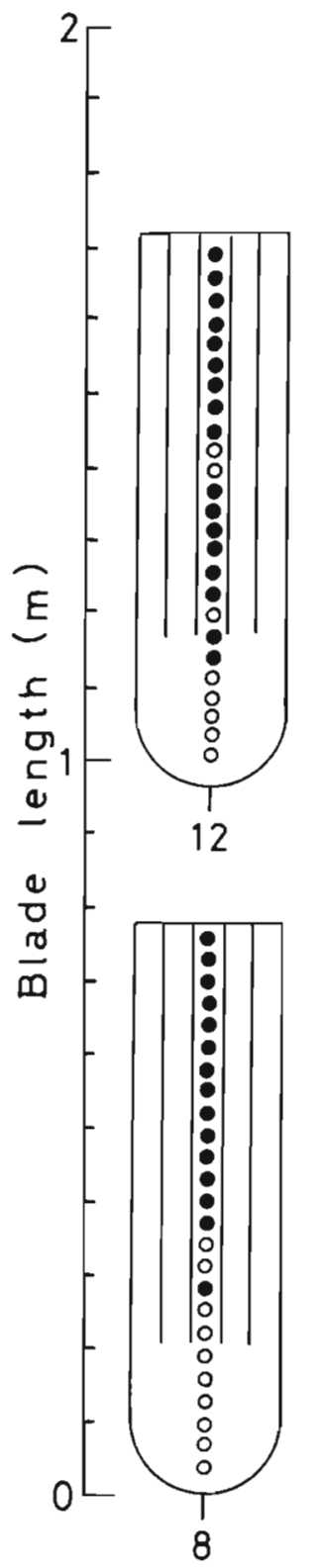

\section{f. STENOPHYLLA}
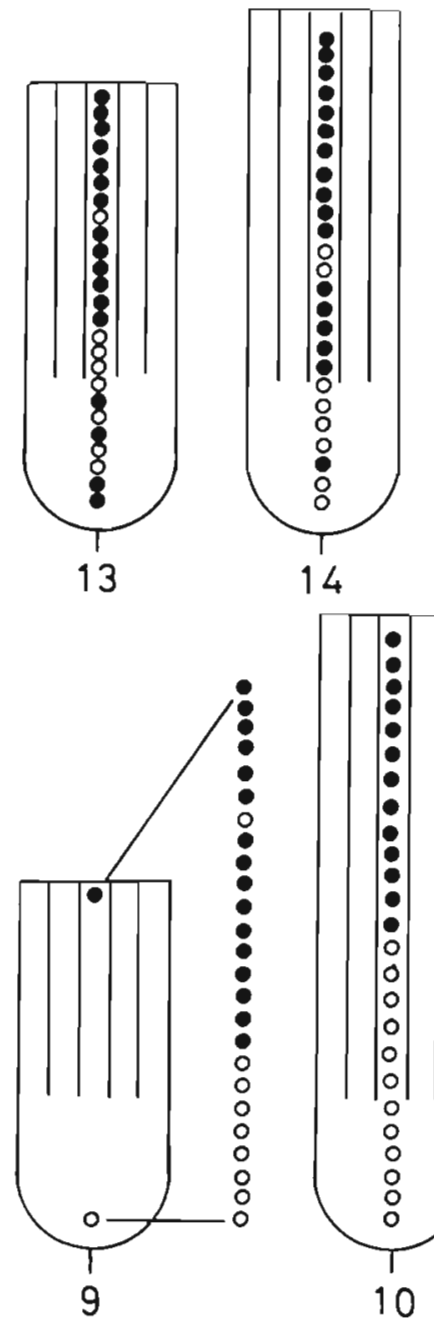

15

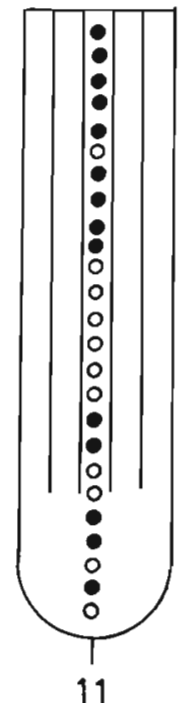

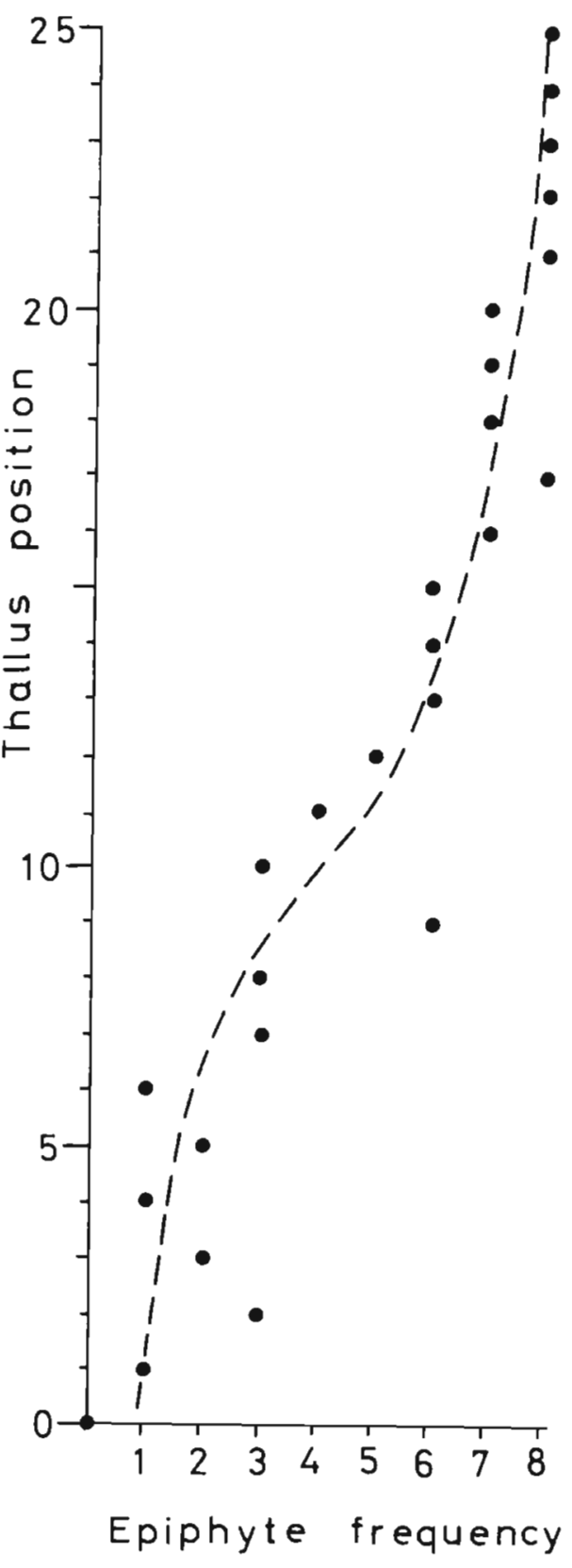

Fig. 4. Laminaria digitata f. stenophylla. Sporophytes, blade length only being to scale. Superimposed upon blade diagrams are positions of the series of punched discs. Filled circles: presence of ectocarpoid algae on cultured discs; open circles: absence. The graph depicts ectocarpoid frequency at each of the 25 positions from which blade discs were removed. Hatched line: best fit

protected from additional epiphyte spore recruitment from outside. The shape of the curve in nature might therefore be expected to alter according to the growth rate of the host and to epiphyte spore availability.

The algal vegetation at Derbyhaven and Scarlett Point has been described by Russell (1977), and it is evident that these habitats are characterised by considerable differences in species composition and abundance. Consequently, the assemblages of algal spores available for colonising Laminaria digitata blades at the 2 sites are likely to be very different in character. Nevertheless, the epiphytes of the 2 sets of discs proved to be virtually identical.

The particular success of Ectocarpus fasciculatus is of theoretical as well as practical importance. The occurrence of this species on a variety of animate and inanimate substrate implies that there is no specific requirement for Laminaria digitata tissues. There is no 

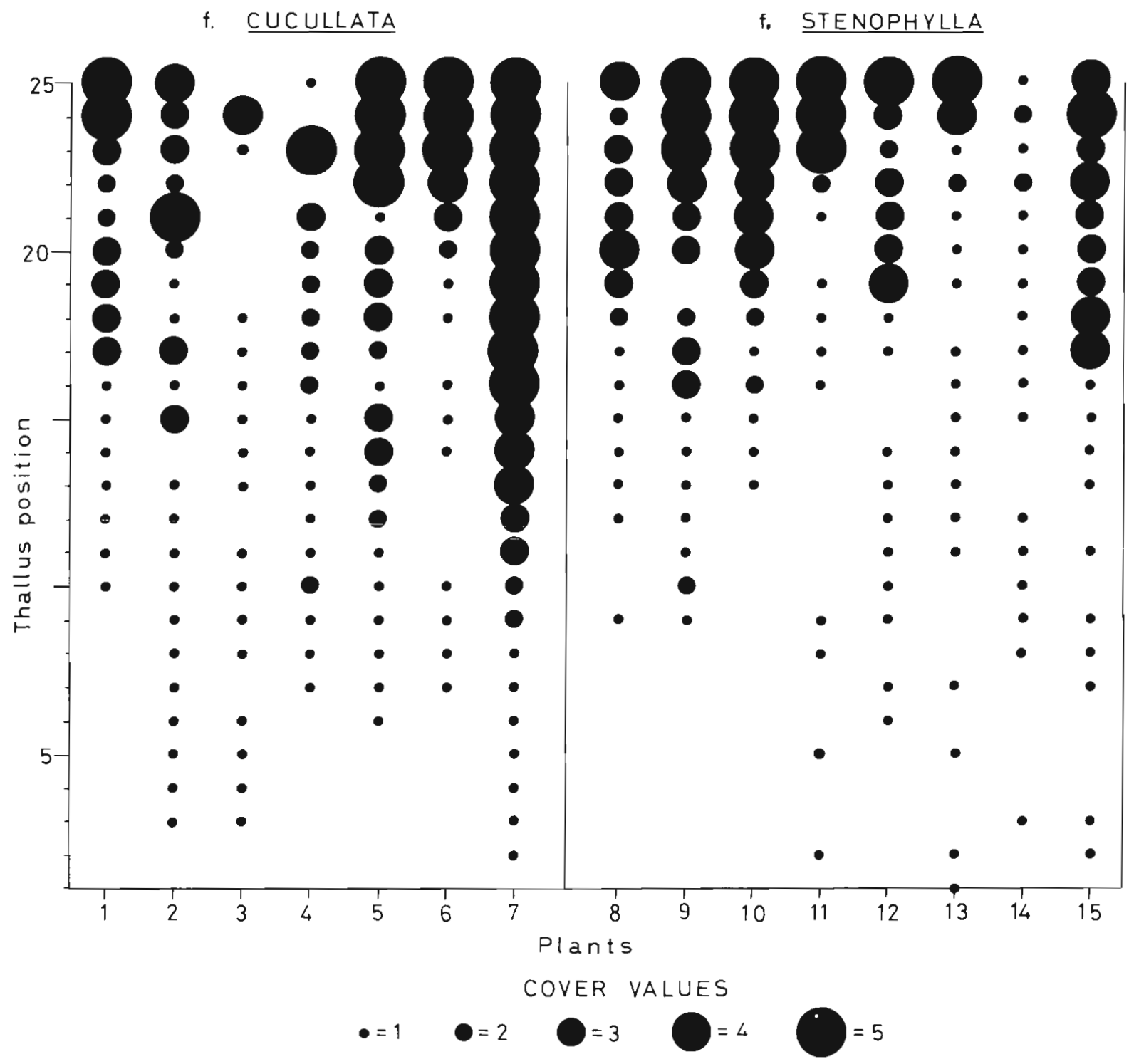

Fig. 5. Laminaria digitata f. cucullata and L. digitata f. stenophylla. Cover abundance of ectocarpoid algae on cultured blade discs. The diameter of each circle denotes the scale of cover at each of the 25 blade positions from which discs were punched; for interpretation of scale see Fig. 1

indication of settlement preference for particular regions of the blade, as shown by bryozoan and serpulid larvae (Stebbing, 1972), nor does the distribution of $E$. fasciculatus follow that of antibiotic activity in the $L$. digitata blade (Hornsey and Hide, 1976, Al-Ogilivy and Knight-Jones, 1977). The existence of some form of chemical recognition on the part of E. fasciculatus cannot altogether be discounted, however

The success of Ectocarpus fasciculatus may be partly due to its ability to exist as a microthallus. The capacity of this form for early reproduction must increase the probability of its offspring maintaining a presence on the host blade during its phase of rapid growth. The macrothallus has been reported to appear on
Laminaria digitata blades during winter, when the rate of host blade growth is relatively slow (Russell, 1966). The relationship between the 2 forms remains obscure, however. A degree of genetic distinction has been reported by Baker and Evans (1971) but the possibility of some extrinsic factor triggering metamorphosis from microthallus to macrothallus, should not be excluded Cold, short-day culture conditions were adopted for their known ability to promote macrothallus development in other simple brown algae (Lüning. 1980); the form of E. fasciculatus in culture was persistently that of the microthallus, however.

In conclusion, the association of Ectocarpus fasciculatus with Laminaria digitata blades seems to be 


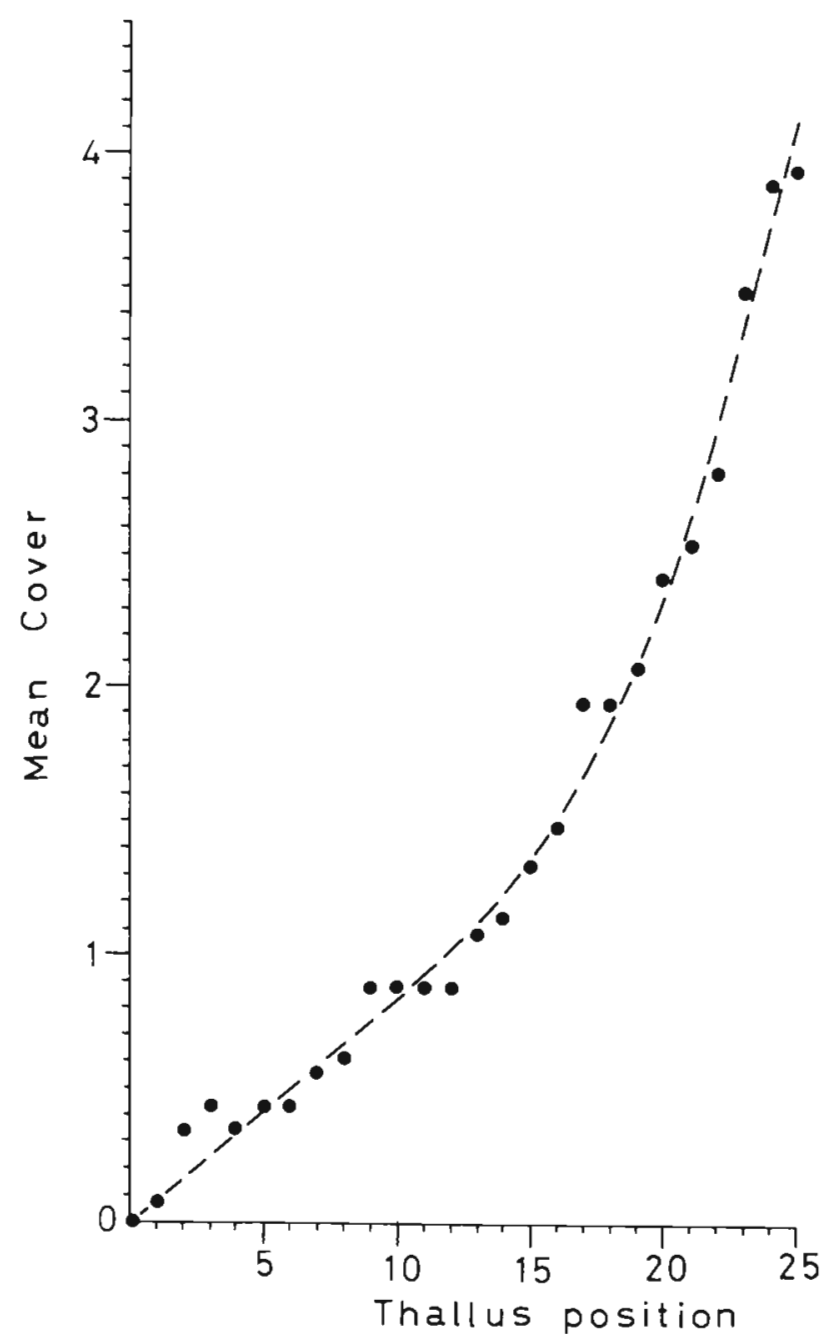

Fig. 6. Laminaria digitata. Mean ectocarpoid algal cover on cultured blade discs calculated from pooled data in Fig. 5. Hatched line: best fit

neither a casual nor an obligate one. It may be best interpreted as the result of a concurrence of a suitable substrate, in the appropriate environment, with an epiphyte possessing particular growth-reproductive characteristics which ensure its survival on the host blade.

Acknowledgements. I am grateful for assistance from $\mathrm{Mr}$ C. J. Veltkamp and Mrs. G. M. Haynes with scanning electron microscopy and disc punching respectively.

\section{LITERATURE CITED}

Al-Ogily, S. M., Knight-Jones, E. W. (1977). Anti-fouling role of antibiotics produced by marine algae and bryozoans. Nature, Lond. 265: 728-729
Baker, J. R., Evans, L. V. (1971). A myrionemoid variant of Ectocarpus fasciculatus Harvey. Br. phycol. J. 6: 73-80

Gayral, P., Cosson, J. (1973). Expose synoptique des donnees biologiques sur la laminaire digitee Laminaria digitata F. A. O. Fish. Synopses 89: 1-58

Harkin, E. (1981). Fluctuations in epiphyte biomass following Laminaria hyperborea canopy removal. In: Levring, $\mathrm{T}$ (ed.) Proceedings of the Tenth International Seaweed Symposium, Göteborg, Aug. 1980. W de Gruyter, Berlin and New York, p. 303-308

Hornsey, I. S., Hide, D. (1976). The production of antimicrobial compounds by British marine algae III. Distribution of antimicrobial activity within the algal thallus. Br. phycol J. 11: 175-181

Jaasund, E. (1965). Aspects of the marine algal vegetation of north Norway, Bot. Gothoburgencia, IV (Acta. Univ. Gotoburg.): 1-174

Kain, J. M. (1971). Synopsis of biological data on Laminaria hyperborea. F. A. O. Fish. Synopses 87: 1-74

Kain, J. M. (1979). A view of the genus Laminaria. Oceanogr. mar. Biol. A. Rev. 17: 101-161

Lüning, K. (1980). Control of algal life-history by daylength and temperature. In: Price, J. H., Irvine, D. E. G., Farnham, W. F. (eds.) The shore environment, Vol. 2, Ecosystems. Academic Press, London, p. 915-945

Lüning, K. (1982). Seasonality in larger brown algae and its possible regulation by the environment. In: Srivastava, L. M. (ed.) Synthetic and degradative processes in marine macrophytes. W. de Gruyter, Berlin, p. 47-64

Marshall, W. (1960). An underwater study of the epiphytes of Laminaria hyperborea (Gunn.) Fosl. Br phycol. Bull. 2: $18-19$

Norton, T.A. (1966). An experimental approach to the autecology of Saccorhiza polyschides (Lightf.) Batt. Ph. D thesis, Liverpool University

Norton, T A. (1970). Synopsis of biological data on Saccorhiza polyschides. F. A. O. Fish, Synopses 83: 1-29

Russell, G. (1966). The genus Ectocarpus in Britain 1. The attached forms. J. mar biol. Ass. UK. 46: 267-294

Russell, G. (1977). Vegetation on rocky shores at some north Irish Sea sites. J. Ecol. 65: 485-495

South, G. R. (1966). An experimental approach to the autecology of Chorda filum (L.) Stackh. Ph. D. thesis, Liverpool University

Stebbing, A. R. D. (1972). Preferential settlement of a bryozoan and serpulid larvae on the younger parts of Laminaria fronds. J. mar. biol. Ass. UK. 52: 765-772

Stosch, H. von (1964). Wirkungen von Jod und Arsenit auf Meeresalgen in Kultur In: Davy de Virville, Ad., Feldmann, J. (eds.) Proceedings of the fourth international seaweed symposium, Biarritz, Sept. 1961. MacMillan, New York, p. 142-150

Sundene, O. (1962). Growth in the sea of Laminaria digitata sporophytes from culture. Nytt Mag. F. Bot. 9: 5-24

Tokida, J. (1960). Marine algae epiphytes on Laminariales plants. Bull. Fac. Fish. Hokkaido Univ. 11: 72-105 